Literature

ӘАәбият

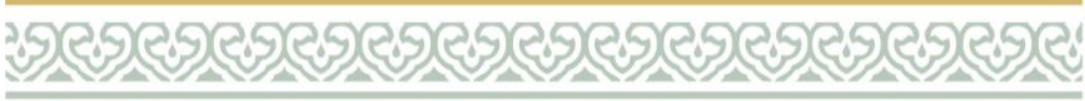

Аитература

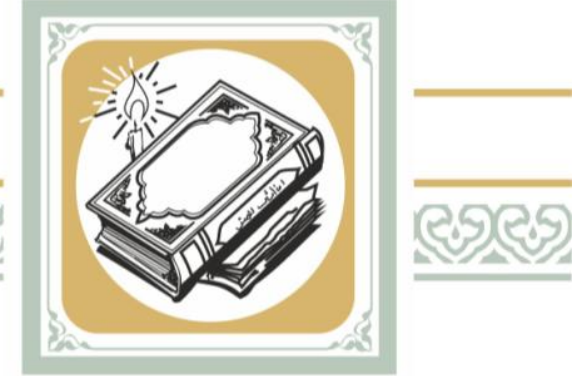

\title{
MUSTAY KARIM AND TATAR LITERATURE: LITERARY MASTERY AND MENTORING
}

\author{
Ildus Kamilovich Fazlutdinov, \\ Bashkir State University, \\ 32 Zaki Validi Str., Ufa, 450076, Russian Federation, \\ fazlutdinov75@mail.ru.
}

\begin{abstract}
Based on modern literary research, the article throws light upon personal and professional relationships between Mustay Karim and Tatar writers. The main methods of this research are chronological and diachronic analyses. The great Bashkir poet M. Karim had a huge impact on the culture of the peoples of the USSR, including literature. The topics discussed in his works are not limited to national context, but are universal in nature. There are three main features characterizing relationships between Mustay Karim, Tatar writes and creative people.

Firstly, Mustay Karim's poetry was inspired by Tatar folklore and the works of the luminaries of Tatar literature: Gabdullah Tukay, Khadi Taktash, Musa Jalil, and Naki Isanbet, which is clearly demonstrated by his artistic thought process and his artistic view of the world In particular, the figurative meanings, used by Gabdullah Tukay, helped Mustay Karim to express reality in a more artistically accurate manner in his early works, thus obtaining associative images, which increase the musicality of his poems.

Secondly, over the years, M. Karim corresponded with his peers Khasan Tufan, Garif Akhunov, Ildar Yuzeev and Tufan Minnullin, and visited them after they had established close personal and professional relationships. They would visit each other, read each other's new work, argue, enriching their works with new poetic techniques and images.

Thirdly, Mustay Karim became a senior writer and a creative mentor for many Tatar poets of the 1960s, such as Renat Kharis, Ravil Faizullin, Marcel Galiev and Robert Minnullin. He was a source of the Turkic peoples' centuries-old wisdom, able to enrich their writing drawing upon his experience. Thus, Tatar literature includes the traditions of the "Mustay Karim School".

Basic concepts: poetry, creativity, individual style, literary criticism, tradition, way of creativity, poetic image, symbol.
\end{abstract}

Key words: poetry, creativity, individual style, literary criticism, tradition, creative method, poetic image, symbol.

Each nation has people who have made major contributions to the promotion of its culture, literature and art. They determine further development of national literature and enrich old traditions with new features, exerting influence on foreign literature. The writer and playwright of the Republic of Bashkortostan Mustay Karim (1919-2005) is one of these people. The poet of the Republic of Bash- 
kortostan Ravil Bikbaev wrote an article "The Epoch of Mustay Karim". The introduction reads, "Creative art, which enjoys great love and deep esteem of its nation, can gain the respect of other peoples. <...>The talent of Mustay Karm, inspired by the Urals, connecting Europe and Asia, preserves the memory of this place, its historical pride as well as the vitality of modern life and our dreams of a better future. At the same time <...> Mustay Karim's oeuvre is connected with the best traditions of Bashkir literature, Eastern and Western literature, world culture and is the treasure of all mankind" [Bikbaev, p. 10]. Obviously, to achieve international recognition, a poet should know the gems of world literature and culture and possess the ability to creatively utilize these literary and aesthetic accomplishments.

First of all, this ongoing process begins with the study of creative development and thousandyear traditions of Tatar literature. This friendly communication with his contemporaries and discussions of different issues with Tatar writers continued throughout the poet's life. Mustay Karim recalled, "Even in adolescence when I was just beginning to familiarize myself with Tatar poetry, I imagined it as three horses, moving on the stone path. $<\ldots>$ These three horses were moving towards me and their gallops sounded like new lines of the verse: Tatar Tukay... Tatar Taktash... Tatar Tufan..." [Karim, 2015, p. 147].

M. Karim's first encounters with the culture and literature of the Tatar people began with the works of Gabdullah Tukay (1886-1913), the poet who "studied Eastern and national traditions in Tatar poetry and enriched them with Arabian aesthetic achievements" [Gilyazov, 2008, p. 45]. He took part in many celebrations, dedicated to anniversaries of the genius and published numerous articles about his life, creative work and poetic world in periodicals. His articles "Tukay", "Being the Happiness of the Tatar People" (1986), "Tukay is 100 Years Old", dedicated to the 100th anniversary of the Tatar poet (1996), and his speeches at the anniversary celebrations were published in Russian and Tatarstan periodicals [Karim, 2015, pp.5762], [Karim, 2016, pp. 251-253 ], [Karim, 2016, pp. 367- 370]. In his articles, M. Karim believed that the Bashkir people were indebted to Gabdullah Tukay. Mustay Karim called him a well-known and prominent educator of the Bashkir people and "the most prominent and beloved" poet who was close to Bashkir literature. "Therefore, in order to keep up with our days, we cling to the hem of Gabdullah Tukay's garb, trying to comprehend the meaning of our dark world. We do not seek consolation or relief, but we do seek support!" [Karim, 2016, p. 368].

In Mustay Karim's poetic world, we find Tukay's traditions of internal nature in his descriptions of reality. According to the literary critic Sufian Safuanov (1931-2009), the works of Mustay Karim possess the image of a poet and a citizen who cares about nations and countries, who is related to the poetry of Gabdullah Tukay. In the poem "Thoughts", his lyrical hero says, "Life is not a holiday, stay calm, I'm just trying to follow the path of my life", he recalls the proud and active lyrical hero who sings the song "I shall not be speechless, even when I see the angel of death".

Mustay Karim's poem "I Am a Russian" pursues the idea that Russians and Bashkirs live peacefully together. Does it have any relation to G.Tukay's patriotic works? [Safuanov, 40-41]. According to the researcher, "in some cases, the details of Tukay's works based on folk art are woven into the figurative features of Bashkir poets' verses and poems, enhancing the emotive atmosphere of these works. M Karim's ballad "The Wind of Dawn" is full of reflections on life and the world. These thoughts create imaginative associations, some of which are quite unexpected. For example, there are details from G. Tukay's poem "The Water Woman".

Maybe this Unhappy Girl

Let her hair loose and,

Being saint and all by herself,

She is looking for her comb

Running around the lake [Translated by A. Ashrapova].

The person who is familiar with literature is able to associate the image of "a stolen comb" in M. Karim's verses with the image of G. Tukay's Water Woman. As a result, the semantic capacity of this gentle image increases, becoming full and sublime [Safuanov, pp. 44- 45]. Researchers of Tukay's work "note the great contribution of the poet's work to the development of cultural ties and the enrichment of the world literary oeuvre" [Gilyazov, 2016, p. 234].

In the epigraph to the article "The Music Is Not Lost" (1997), dedicated to composer Zahir Ismagilev (1916-2003), M. Karim used Gabdullah Tukay's verses to reveal his philosophical thought: "Is the fire of my poem alive? - I am still able to carry a mountain despite my age" [Karim, 2016, pp. 376-377]. Thus, Tukay's imagery was a school of literary excellence for M. Karim, which enabled 
him to create new images and increased the musicality of his works.

Mustay Karim expressed his deep respect, gratitude and appreciation for the classics of Tatar literature. In 1938 and 1997, he wrote two poems "To Tukay" and worshipped his talent. [Karim, 2009, p. 33], [Karim, 2011, p. 204]. The first poem is dedicated to the image of Tukay, seen through the prism of revolutionary poetry aesthetics and a social viewpoint /The young man died in the stuffy atmosphere of outdated approach/. The second poem reveals the feeling of universal appreciation for the poet (For sixty-three years I have appreciated you, for sixty-three years I have missed you). When the writer, poet and literary critic Akhmet Faizi (1903-1958) was first awarded the State Prize of the Republic of Tatarstan named after Gabdullah Tukay, Mustay Karim devoted his poem "Forgive Me Death" to G. Tukay and A. Faizi to express his sincere appreciation [Karim, 2011, p. 236].

In the 1980s, the era of "perestroika", we lost certain national values and spiritual ideals. Therefore, the works of some Soviet Tatar classical writers, which did not meet the new requirements, were jettisoned. Mustay Karim was against it, conveying his negative attitude in his poem "Three Pegasus" (1991). He called such poets as Tukay, Taktash and Tufan the supporters and defenders of the Tatar soul [Karim, 2011, p. 148]. In the poem "Travelling" (2001) he linked the poets' birth places with the talent of these people: Tukay was born in Kushlavich, Taktash was born in Syrkudy, Tufan was born in Old Kermet. He expressed his deep gratitude to these holy places. [Karim, 2011, p. 233]. Mustay Karim admired the talented soul of the Tatar poets' lyrical hero in the poem "Impromptu" (2004):

Some of them were not aged thirty

Like Tukay, Babich, Taktash.

I am an old man of eighty-five

What should I do, my darling? [Karim, 2011, p. 245].

All his life Mustay Karim appreciated the three "T's" of Tatar literature - Tukay, Tahtash and Tufan. He was inspired by their works when he mastered the skill of writing poems. He valued their works and believed them to be his guiding light. Unfortunately, he did not meet Tukay and Tahtash in person, but Khasan Tufan was his poetic mentor and close friend.

Young Mustay Karim became familiar with the personality and works of Khasan Tufan (19001981) in the 1930s - it was during his studies at Kalachevskiy school in the Chishminsky district of
Tatarstan. He wrote about his first impressions of the writer. "Our first meeting aroused unusual feelings. I was a little bit disappointed. Kh. Tufan had a very serious face. He had dishevelled hair (I'd rather he had curly hair like Pushkin - M. K.). He was like a bell ringer from Bogolyubov Church in our neigbouring village. This bell ringer was my father's acquaintance. Of course, I described the image of Khasan Tufan on the pages of the textbook" [Karim, 2016, pp. 253-254]. Although Tufan's appearance was not remarkable, his poetry was breathtaking. His works made a great impression on Mustay Karim. "The thoughts and images of his poems are not like small red berries seen above long leaves, but like large tasty berries we find under the leaves. I need years to see and find them. One day I fell in love with his writing and I was eager to follow his example. I tried to write the poem "Autumn Wish" imitating Khasan Tufan. But I failed. To write like Khasan Tufan, you need to be Khasan Tufan. By the way, this poem was the only poem of mine that Khasan Tufan had seen. Khasan Tufan said, "After reading the poem I thought this was a promising young man". For sixteen long years, they kept telling us: "Forget it. He's gone". Although we did not know the truth, one's heart and soul could not forget, so we did not obey the false order [Karim, 2016, p. 260].

The poets first met in June 1956. Mustay Karim returned from his exile. Khasan Tufan was the only Baskir poet who came to meet him at the Kazan railway station [Karim, 2016, pp. 260-261]. They became close friends and would meet at least once a year. [Tufan, 2010, pp. 172-194]. According to his diaries, Khasan Tufan was in Ufa on January 10-16, 1963. M. Karim met him at the Ufa railway station and saw him off to Kazan. He took part in the meeting of the Writers' Union of the Republic of Bashkortostan, delivered a speech addressing the students of Bashkir State University, and met with his pen pals Kadir Diyan, Bayazit Bikbai, Saifi Kudash, Gyilemdar Ramazanov, Ibrahim Abdullin, Rami Garipov, Musa Gali, Nazhar Nazmi, Farit Isangolov, Akhtam Mansur, Rafael Safin, famous playwrights Arslan Mubarak, Farida Kudasheva and others. Wherever Khasan Tufan went, Mustay Karim accompanied him. [Tufan, 2010, pp. 172-173]. On February 7-11, 2012, Mustay Karim visited Kazan. He participated in the meeting of the Writers' Union of the Republic of Tatarstan. During these days, he did not stop at a hotel, he was a guest of Khasan Tufan's and stayed with him. 
Apparently, the two writers' friendship was very close, because he never mentioned any personal facts about Khasan Tufan in his diaries. For example, on February 7, the diary had only one entry: "...I have burnt my letter to Kazan. I do not like that malice to be sent to Kazan". What was in that letter? Was it the letter with Khasan Tufan's false denunciation (in this case: the letter to Bashkir intellectuals)? Or was it Mustay Karim's response? It might have been that letter to Kazan criticizing the Bashkir writer.

There are three letters sent to Mustay Karim by Khasan Tufan in 1960. These letters are filled with deep respect and love for Mustay Karim and his works. In 2010, they were published in M. Karim's five-volume collection of works. At the same time, Khasan Tufan was quite modest in evaluating his own poetry. For example, Khasan Tufan wrote in his diary on September 1, 1960: "I am happy for you, not for myself. I am a poet only in a few of my verses. And you are a poet not only in your poems, but also in your articles and in your speeches, in Kazan, in the Caucasus and in Moscow; at parties and events. We miss not only our past but also our future. You possess a desire for creative work, for a living future. There is one unique feature in you: you have a strong ability to feel the boundaries of the future, and feel them very clearly. You really believe in the beauty of our future: in its days and nights, in each hour and every moment. Your poems, each new poem fills me with happiness: I am a reader. And I am quite a good reader who is still seeking the good" [Tufan, 2010, p. 284].

Kh. Tufan's letters to his friends and writers from Ufa are evidence of his thoughts on the Bashkir writer. In 1978, he sent a congratulatory telegram on the 60th birth anniversary of Nazhar Nazhmi. It runs as follows: "These are my brothers and sisters who are the leading light of literature of Bashkortostan and Tatarstan. They are Bashir (Gumar Bashirov), Sibgat (Sibgat Khakim), Mustai and you, Nazhar" [Tufan, 2010, p. 286]. It is worth noting that the poet, who had been betrayed more than once in the 1930s, was very selective about his friends. Khasan Tufan wrote to his groupmate and friend Saifi Kudash about their true friendship and his respect to Mustay Karim (1894-1993). They went to madrasa Galiya together.

In his letter on April 22, 1963, Kh. Tufan wrote that he appreciated Mustay Karim for his great wisdom and diplomatic skills. He informed his friend about books to be printed in the Tatar language in the Bashkir book publishing house.
Khasan Tufan advised the national poet of Bashkortostan Saifi Kudash to collaborate with Mustay Karim. "I would like this important issue to be more than good will, I do not want it to remain an unapproved desire" [Tufan, 2010, p. 242]. Indeed, the publishing house began printing books in the Tatar language, in the mid-1960s several collections were published. Unfortunately, it was not a long- term project at that time. Nevertheless, publishing in the Tatar language was resumed on a regular basis only in the 1990s in the Republic of Tatarstan, owing to Khasan Tufan's great experience and his trust in Mustay Karim's authority.

Khasan Tufan wrote several poems dedicated to Mustay Karim. They were in Kazakhstan together participating in an event, promoting Tatar literature and culture. On the way home, on the train, he wrote a poem "Feeling Tired after a Party" [Tufan, 2008, p. 70] and the poem "Gamzat is our Rasul" (1969) [Tufan, 2007, pp. 439-440]. He visited the village Kelash in 1967 and wrote the poem "The Wind Calms Down and the Birches Are Quiet". [Tufan, 2007, p. 80]. In addition to poems Khasan Tufan wrote critical and journalistic articles. In 1969, the magazine "Azat Khatyn" ("A Free Woman") published his article praising Mustay Karim's personality, his poetic gems and the value of national spiritual heritage [Tufan, 2010, pp. 45-46].

This literary friendship and collaboration was maintained by both poets. Mustay Karim wrote the poems "Three Horses" (1991) [Karim, 2011, p. 148] and "What Does the Nightingale Need a Figure for..." (1968) [Karim, 2011, p. 317] dedicated to Khasan Tufan. In the work "It was the Sunrise Time" (2001) he depicted the meeting of the two poets in Tufan's house, located in the suburbs of Kazan in the village of Swan Lake [Karim, 2011, p. 229]. In the poem "Kazan", written in 2001, Mustay Karim expressed his love for the capital city via the genius Khasan Tufan [Karim, 2011, p. 228]. As an epigraph, he chose the words from Kh. Tufan's poem (1994) "I Dreamt I Saw Allah", introducing his poem "I Dreamt I Saw God" [Karim, 2011, p. 176]. Mustay Karim wrote an introduction to Tufan's book "Poems from Soul", published in 1960 in Ufa [Tufan, 1960, pp. 3-18]. Many articles by Mustay Karim, devoted to the works of Khasan Tufan, were published in periodicals [Karim, 1960, 14 December], [Karim, 1970, pp. 106-112], etc. It is evident that Mustay Karim devoted one thematic branch of his oeuvre and his spiritual heritage to Khasan Tufan. 
Mustay Karim strengthened his personal and literary relationships with Tatar writers in the years of the Great Patriotic War. In this regard, his journalistic activities in front-line newspapers should be noted. In his autobiographical work "Moments of Life", Mustay Karim recollects that in 1943 he was sent to work for a Bashkir newspaper, which operated on the Voronezh front. However, the publication was not released for some reasons. Later, Mustay Karim worked for the periodical "For the Honor of the Motherland", published in the Russian language. At the same time, the newspaper "Watan namusy uchen" (For the Honor of the Motherland) in the Tatar language was released. M. Karim quickly made friends with Tatar intellectuals who worked with the Tatar newspaper, they were writers Akhmet Erikay (1902-1967) and Gali Khuzi (1912-1966), playwright Riza Ishmurat (1903-1995). They lived and worked side by side. According to him, veteran writers enjoyed these friendly ties until the end of their lives [Karim, 2015, pp. 498-499].

In the summer of 1943, M. Karim was appointed to work for the Tatar edition of "The Soviet Warrior" on the Third Ukrainian front. Its editorin-chief was the Tatar writer and translator Mahmud Masgut. The Bashkir poet was familiar with the literary oeuvre of M. Masgut as early as before the war. When they met in person, M. Karim and M. Masgut made a favourable impression on each other and maintained friendly relationships for two years until the end of the war. M. Masgut immediately felt that Karim was a talented writer and provided occasions for him to display his literary talent. In the book "Moments of Life" he mentions that the poetic cycle "The Foreign Fire", the third part of his poem "Ulmasbay" and the poem "The Letter of Response to the Bashkir People" were written in those years [Karim, 2002, pp. 168-174].

M. Karim always recalled M. Masgut as a deeply intelligent, fair and demanding leader. The Tatar writer studied German to translate the works of Heinrich Heine into Tatar. His wish was to translate "Faust" by Goethe into Tatar. M. Masgut was a close friend of the poet-patriot Musa Jalil and his in-law relative [Karim, 2015, p. 503]. At the end of the Great Patriotic war, M. Masgut and M. Karim started their search for the missing poet, but to no effect. In the article "The Beginning of Immortality", the Bashkir poet describes in detail their attempts to find Musa Jalil (1966) [Karim, 1999, pp. 234-238]. M. Karim had met the great Musa Jalil (1906-1944) on Herzen Street in Mos- cow in the autumn of 1940 . At that moment M. Jalil was talking to Bashkir writer Amir Chanish [Karim, 2015, p. 74]. After the war, M. Karim devoted several articles to the Tatar poet [Karim, 1954, p. 94], [Karim, 1966, p. 27, February], [Karim, 2015, pp. 73-77]. He wrote the introductory part to the book "Selected Works" by Musa Jalil, published in the Russian language in 1976 in Moscow [Karim, 2015, pp. 547].

M. Karim greatly appreciated the scientific and literary work of the outstanding Tatar scientist, folklorist, playwright and poet Naki Isanbet (18991992). They met several times, regularly corresponded and talked on the phone. One of their meetings was in May 1960 in the village of Kokushkino, Tatarstan. Mustay Karim described it in his book "Moments of Life" [Karim, 2015, p. 521]. For the epigraph he chose the line "Putting the reaping-hook on the shoulder..." from the poem "The Reaper Girl" by N. Zhiganov [Karim, 2015, p. 251]. Later this poem was translated into the Russian language" [Fazlitdinov, Khaliullina, p. 701].

In his articles and interviews, M. Karim emphasized his constant personal and creative friendship with the representatives of Tatar literature: "These are my friends: Garif Akhunov, Tufan Minnullin, Ildar Yuzeev, of course, Renat Kharis. There is also Rinat Mukhammadiev, Ravil Faizullin, our countrymen Akhsan Bayan, Robert Minnullin, Gatash... Thank God, I have many friends in Kazan" [Karim, 2016, p. 321]. His friendship with Garif Akhunov (1925-2000), the People's poet of the Republic of Tatarstan, the laureate of the State Prize of the Republic of Tatarstan named after G. Tukay, began in the mid-1960s. The Tatar writer often visited the Bashkir poet and was the host of his anniversary events. Mustay Karim also participated in the official anniversary celebrations of Garif Akhunov. One of his speeches, made at the anniversary event "Let Life Be Long, but Old Age Be Short", was published in the $9^{\text {th }}$ volume of the Bashkir writer's "Selected Works" [Karim, 2015, pp. 354-356]. Not only the literary work of the Tatar national writer, but also his name enriche the poet's lyrical patterns, deepening his philosophical ideas. In particular, M. Karim uses his name as a symbol of the city in his poem "Kazan" [Karim, 2011, pp. 228].

From the very beginning of his literary career path M. Karim was objective in expressing his attitude to literary trends, the development of Tatar drama, its achievements and shortcomings. In June 1974, in Ufa, at a meeting of Bashkir and Tatar 
playwrights, directors of national theatres and art critics, he noted that Bashkir theatre stemmed from Tatar drama. In his interview to the newspaper "Socialist Tatarstan" (October 24, 1980) he said, "when looking at Tatar drama art, we cannot remain indifferent to the current state of this kind of art: we rejoice in its success when we learn the good news, and get upset when we see its failures." He also admired the dramas of Tufan Minnullin (1935-2012): "he is able to get his word across to the people of the whole Soviet Union" [Karim, 2017, p. 123]. Being familiar with the works of T. Minnullin, a national writer, publicist and public figure of the Republic of Tatarstan, M. Karim called him the coryphaeus of national culture. They had close relationships, therefore, they often had disputes about literature and national problems. The Tatar playwright mentioned their discussions and friendly disputes in his diaries and articles [Minnullin, 2002, Vol. 7, p. 45], [Minnullin, 2002, Vol. 7, p. 268], [Minnullin, 2002, Vol. 8, pp. 416418], [Minnullin, 2002, vol. 10, pp. 239-243]. At the Second World Congress of Tatars M. Karim presented his book to the Tatar writer. He signed it and wrote the following words "From a humble teacher to his successful student" [Minnullin, 2002, Vol. 8, p. 417]. One interesting fact concerning the episodes from the drama by Tufan Minnullin: he saw in his dream the denouement of the drama "Kushigyz" ("Good Bye") after seeing Mustay Karim's drama "Kyz Urlau" ("Stealing the Bride") [Minnullin, 2002, Vol. 8, p. 104]. Despite the fact that in some matters their opinions differed, the two classics of the related literatures respected each other's work.

M. Karim had close professional and personal relationships with Tatar writers Renat Kharis, Robert Minnullin, Marcel Galiev and others. In 1997, he wrote a review of the collection of poems "My Feelings Name" as R. Kharis was nominated for the State Prize of the Republic of Tatarstan named after Gabdulla Tukay. His review "The Mind Loves, the Words Play" throws light upon the interactions of Arabian-Russian-Tatar literatures and the similar ideas in the works of Fyodor Tyutchev (1803-1873), Derdmend (1859-1921), Khasan Tufan (1900-1981) and Garcia Lorca (1898-1938). M. Karim depicted the literary world of the poet with the verses of Derdemend [Karim, 2016, p. 382] and dedicated his poem "Morning Wishes" (2004) to Renat Kharis [Karim, 2011, p. 244].

Mustay Karim was 27 years older than Marsel Galiev but they had a lot in common. They had similar creative views, and their friendly relationship is reflected in the article "The Cap of Marsel Galiev" [Karim, 2016, pp. 375-376]. There are a lot of verses dedicated to the life and creative work of his countryman Robert Minnullin. His humorous and emotional poem "New Year Greetings to Friends" (2002) shows his respect to the poet Ravil Faizullin. For an epigraph to his poem "Travelling", Mustay Karim chose the lines from R. Minnullin's poem "The Poet's Native Country": My friends go abroad/ They ask me to join them/ They follow their dreams/ to the places of Byron and Tagore [Karim, 2011, p. 235].

In his article "Boyhood. Skills. Mentoring..." (1999), the People's Poet of the Republic of Tatarstan R. Minnullin wrote about M. Karim: "Undoubtedly, he is the writer who can be placed on a par with the classics of world literature and compete with them" [Minnullin, 2007, Vol.5., pp. 182-184]. A literary event "Limitless Mustay!" was held on October 14, 2004, in Nizhnekamsk. Mustay Karim was invited to a meeting with literature fans by the amateur theatre association "Zhidegen Chishma" (Seven Springs). R. Minnullin contributed an article about this meeting [Minnullin, 2007, pp. 272-278]. In an interview to the Ufa newspaper "Week", he said, "Mustay Karim is a person very dear to me. He has been my mentor, my favourite poet since my childhood. Despite the difference in our age, we are like-minded people. We have been on the same page over these 10-15 years. We keep in touch, discussing some issues. We exchange letters and talk on the phone. He calls, mostly <...>. He is my mentor, and I have learned a lot from him" [Minnullin, 2007, Vol. 7, p. 458].

M. Karim maintained close friendly relations both with his Tatar colleagues and with stage figures. In 1994, the famous Kazan singer Khaidar Begichev (1949-1998) came to Ufa to celebrate his 75th anniversary. After this meeting, M. Karim fell in love with the work and personality of the Tatar singer and closely followed his achievements. Their relationship was full of respect, care, and kind feelings. Having learned that the singer got into a car accident in 1995, he went over to Raul Mir-Khaydarov's house in Moscow and met Amirkhan Eniki, a writer, a classic of Tatar literature. He asked that his sympathy to the singer be passed on and left his poem and a letter, addressed to the singer [Karim, 2016, p. 374]. This poem with the dedication "to Khaidar Bigichev" was published in his book "Works" [Karim, 2011, p. 198]. 
In the article "He Himself Is the Era" (2005), M. Karim showed his great respect to Ilham Shakirov, the legend of the Tatar stage, the Laureate of the Republic of Tatarstan State Prize named after G. Tukay (1835-2019). He admired his voice and called him "a wonderworker, a magician". "Great musician Sarah Sadykova has composed music to my lyrics "It Has Kept Snowing for Three Days". When I. Shakirov was singing this song it seemed that the pain in my heart that had been twinging my body for years was lifted by him. He sings, but red drops from his broken heart keep falling on the white snow..." [Karim, 2018, p. 36].

Speaking about the relationships between Mustay Karim and the representatives of Tatar culture, it is impossible to ignore the issue of their native (Tatar) language, its fate, the status of the Tatar language in Bashkortostan, which worries every Tatar intellectual. In numerous conversations and interviews the poet expresses his opinion that only one language is to have national status - Bashkir in the Republic of Bashkortostan. The Russian language automatically becomes the state language. At the same time, during a heated debate with Bashkir intellectuals in 1992, Mustay Karim expressed the following opinion: "based on today's reality, the Tatar language should be given a special status. In addition to the state language, we must admit the Tatar language is widely used in education, culture, press, radio-television, and office work. Evidently, the professionals determine its terminology" [Karim, 2017, p. 186]. Judging by these words, Mustay Karim appears to be a deep thinking and truly broad-minded person.

The great Bashkir poet Mustay Karim has had a great influence on the art and culture of speech of the peoples of Russia and the USSR. The topics discussed in his works have both national and universal meaning. Based on these observations, we can distinguish three Mustay Karim's characteristic features in relation to Tatar literature and culture, which is historically, spiritually and culturally very close to the Bashkir people. Firstly, Tatar folk art and the luminaries of Tatar literature G. Tukay, Kh. Taktash, M. Jalil and N. Isanbet had an impact on the poetry of Mustay Karim. It is clearly manifested in the poet's figurative thinking and his creative works. Secondly, over the years, he established close personal and professional friendly relations with his Tatar contemporaries Khasan Tufan, Garif Akhunov, Ildar Yuzeev and Tufan Minnullin. These writers enriched each other's works with new artistic images and techniques. Thirdly, Mustai Karim was not only the senior au- thority for the younger generation of Tatar writers R. Kharis, R. Faizullin, M. Galiev and R. Minnullin, but also their creative mentor, a source of the Turkic peoples' millennial wisdom. Thus, there is every reason to believe that Tatar literature includes the traditions of the "Mustay School". According to the Bashkir poet R. Bikbayev, it is his "vitality and humanity, philosophical depth of his thought and feelings, ingenuity, originality and uniqueness of his personality" [Bikbaev, p. 11]. Thus, it is the personality and creative art of Mustay Karim that have created a kind of spiritual and cultural bridge between Tatar and Bashkir verbal arts, have made a contribution to the establishment of good relations between the two nations, have acquainted people with the artistic gems, created by natural talents, and helped to exchange cultural experiences.

\section{References}

Bikbaev, R. (2009). Mustai Karim davere [The Epoch of Mustay Karim]. Karim Mustai. Eserler.1 Tom. Shigyrlar. Pp. 7-18. Ufa, Kitap. (In Bashkir)

Fazletdinov, I. Khaliullina, A. (2018). Tatarstannan chitta izhat itelgen edebiiatta Tatar motivlary [Tatar Motives in Literature Created Outside of the Republic of Tatarstan]. Tatar edebiiaty tarihy 8 tomda 6 Tom.: 1960-1980 ellar /tuz R. F. Rakhmani, fenni muh. D. F. Zahidullina, A. M. Zakirzhanov. Pp. 696-736. Kazan, Tatar kit neshr. (In Tatar)

Gilazov, T. Sh. (2008). Osnovnye tendentsii razvitiia tukaeiedeniia na rubezhe XX-XXI [The Main Trends of Tukay Studies at the Turn of $20^{\text {th }}-21^{\text {st }}$ Centuries]. Uchenye Zapiski Kazanskogo Gosudarstvennogo Universiteta. Tom 150, kniga 8. Gumanitarnye nauki. Kazan, izd-vo Kazanskogo gosudarstvennogo universiteta. Pp. 42-47. (In Russian)

Gilazov, T. Sh. (2016). Akademicheskoe sobranie sochinenii Gabdully Tukaia: istoriia struktura $i$ printsipy sostavleniia [Academic Collection of Gabdulla Tukai's Works: History, Structure and Principles of Compilation]. Philology and Culture. Pp. 230-237. (In Russian)

Karim, M. (1973). Izbrannoe: stihotvoreniia, poemy, skazki, tragedii [Selected Works: Verses, Poems, Fairy Tales, Tragedies]. 152 p. Moscow, Hudozhestvennaia literatura. (In Russian)

Karim, M. (1988). Pritcha o trekh bratyah [The Parable of Three Brothers]. 367 p. Moscow, Sovremennik. (In Russian)

Karim, M. (1982). Stihi i poema [Verses and a Poem]. Per s bashkir yaz. 256 p. Moscow, Sovetskaia Rossiia. (In Russian)

Karim, M. (1982). Ushel ne pomnya zla [Gone, Remembering No Evil]. Vecherniaia Kazan, 12 October. (In Russian)

Karim, M. (2002). Gumer Mizgellere [Moments of Life]. 336 p. Ufa, Kitap. (In Bashkir) 
Karim, M. (1954). Zhyr hebersez yugalmady [The Song Is Not Lost]. Sovet edebiyaty. No. 1, 94 p. (In Tatar)

Karim, M. (1966). Ilebez gorurlygy [The Pride of Our Country]. Sovet Tatarstany. 27 February. (In Tatar)

Karim, M. (1970). Yoregemde etmesh yaz yurtese [Seventy Springs in My Heart]. Agizel, No.12, pp. 106112. (In Bashkir)

Karim, M. (1960). Kartaimauchy shagyirler shagyire [The Poet of Ageless Poets]. Kyzyl Tan, 14 December. (In Tatar)

Karim, M. (2006). Kondelekler [Dairies]. Agizel. No. 10, pp. 5-39. (In Bashkir)

Karim, M. (1999). Eserler: 5 tomda. 4 Tom: istelekler, mekeleler, telmerler, engemeler. [Works in Five Volumes. Vol. 4: Memoirs, Articles, Interviews]. 592 p. Ufa, Bashkortostan Kitap neshriete. (In Bashkir)

Karim, M. (2009). Eserler. 1 Tom: Shigurlar. [Works. Vol. 1: Poems]. 512 p. Ufa, Kitap. (In Bashkir)

Karim, M. (2011). Eserler. 2 Tom: Shigurlar. Shigri tergemeler [Works. Vol. 2: Poems and Translations of Poems]. 416 p. Ufa, Kitap. (In Bashkir)

Karim, M. (2015). Eserler. 6 Tom: Khatiralar, Edebi Hyiratlemeler. [Works. Vol. 6: Memories. Literary Thoughts]. 560 p. Ufa, Kitap. (In Bashkir)

Karim, M. (2016). Eserler. 7 Tom: Sailanma publithsistic yazmalar. [Works. Vol. 7: Selected Journalistic Articles]. 568 p. Ufa, Kitap. (In Bashkir)

Karim, M. (2017). Eserler. 8 Tom: Sygyshtar. Telmerzer, engemeler. [Works. Vol. 8: Memories, Speeches, Interviews]. 472 p. Ufa, Kitap. (In Bashkir)

Karim, M. (2018). Eserler. 9 Tom: Mekelletr, sygyshtar. Telmerzer, engemeler. [Works. Vol. 9: Articles, Memories, Speeches, Interviews]. 520 p. Ufa, Kitap. (In Bashkir)

Minnullin, R. (2007). Eserler: 7 tomda. Tom 5: izhat portretlary, notyklar mekeller [Works in Seven Volumes. Vol. 5: Creative Portraits, Reports, Articles]. 431 p. Kazan, Tatar kit neshr. (In Tatar)
Minnullin, R. (2007). Eserler: 7 tomda. Tom 6: publitcsistica, istelekler, notyklar [Works in Seven Volumes. Vol. 6: Journalistic Articles, Memories, Reports]. 527 p. Kazan, Tatar kit neshr. (In Tatar)

Minnullin, R. (2007). Eserler: 7 tomda. Tom 7 mekeleler, yulyazmalar, retcsenziyaler, engemeler [Selected Works in Seven Volumes. Vol. 7: Articles, Itineraries, Reviews, Interviews]. 431 p. Kazan, Tatar kit neshr. (In Tatar)

Minnullin, R. (2002). Sailanma Eserler: 10 tomda. Tom 7: kundelekler (1980-1991ellar) [Selected Works in Ten Volumes, Vol. 7: Diaries (1980-1991)]. 448 p. Kazan, Tatar kit neshr. (In Tatar)

Minnullin, R. (2002). Sailanma Eserler: 10 tomda. Tom 8: kundelekler (1980-1991ellar) [Selected Works in Ten Volumes, Vol. 8: Diaries (1980-1991)]. 479 p. Kazan, Tatar kit. neshr. (In Tatar)

Minnullin, R. (2002). Sailanma Eserler: 10 tomda. Tom 10: Engemeler, mekeleler [Selected Works in Ten Volumes, Vol. 10]. 400 p. Kazan, Tatar kit. neshr. (In Tatar)

Safuanov, S. (2006). Rukhi kuperler [Moral Bridges]. 376 p. Ufa, Kitap. (In Tatar)

Tufan, Kh. (1960). Kunel defterenen shigyrzar [Poems from the Soul Book]. Keresh huz avt. M Karim. 208 p. Ufa, Bashkortostan kitap neshriete. (In Bashkir)

Tufan, Kh. (2007). Sailanma eserler 5 tomda. Tom 2: shigyrler poemalar [Selected Works in Five Volumes. Vol 2: Verses and Poems]. Tozuchese Masgud Gainetdinov. 463 p. Kazan, Tatar kitap neshr. (In Tatar)

Tufan Kh. (2008). Sailanma eserler 5 tomda. Tom 3: shigyrler poemalar [Selected Works in Five Volumes. Vol 3: Verses and Poems]. Tozuchese Masgud Gainetdinov. 415 p. Kazan, Tatar kitap neshr. (In Tatar)

Tufan, Kh. (2010). Eserler 5 tomda. Tom 4: mekeller. Kundelekler, khatlar, turle yazmalar [Works in 5 volumes. Vol 4: Articles, Diaries, Letters, different writings]. Tozuchese Masgud Gainetdinov. 303 p. Kazan, Tatar kitap neshr. (In Tatar)

\title{
МОСТАЙ КӘРИМ ҺӘМ ТАТАР ӘДӘБИЯТЫ: ӘДӘБИ ОСТАЛЫК ҺӘМ ОСТАЗЛЫК
}

\author{
Илдус Камил улы Фазлетдинов, \\ Башкорт дәүләт университеты, \\ Россия, 450076, Уфа ш., Зәки Вәлиди ур., 32 нче йорт, \\ fazlutdinov75@mail.ru.
}

\begin{abstract}
Мәкаләдә Мостай Кәрим белән татар әдипләре арасындагы шәхси һәм ижади бәйләнешләр хәзерге әдәбият белеме ирешкән казанышлар ноктасыннан бәяләнә. Гыйльми-хронологик һәм диахроник анализ фәнни эзләнүләрнең төп ысулы булып тора. Автор билгеләгәнчә, башкорт халкының бөек шагыйре М. Кәрим СССР халыкларының мәдәниятенә, шул исәптән сүз сәнгатенә дә зур йогынты ясый; аның ижатында күтәрелгән проблемалар бер милли кысалар белән чикләнми, ә гомумкешелек яңгыраш ала. М. Кәримнең тугандаш татар халкының әдәбияты һәм мәдәнияте вәкилләре белән шәхси һәм ижади бәйләнешләре тарихында өч үзенчәлекне аерып чыгарырга мөмкин.
\end{abstract}


Беренчедән, М. Кәрим шигърияте татар фольклорыннан, татар әдәбияты корифейлары Габдулла Тукай, Һади Такташ, Муса Жәлил, Нәкый Исәнбәт тудырган традицияләрдән үсеп чыккан. Бу үзенчәлек шагыйрьнең сәнгати фикерләвендә дә, ижатындагы дөнья картинасында да чагылыш таба. Аерым алганда, Тукайдагы образлылык шагыйрь өчен чынбарлыкны сәнгатьчә чагылдыруда этәрелеп китү ноктасы булып хезмәт итә, яисә ассоциация ярдәмендә яңа образлар тудырганда катнаша, әсәрләрендәге музыкальлекне арттыра.

Икенчедән, еллар үтү белән, М.Кәрим, үзенең каләмдәшләре Хәсән Туфан, Гариф Ахунов, Илдар Юзеев, Туфан Миңнуллиннар белән тыгыз шәхси һәм ижади дуслык мөнәсәбәтләре урнаштырып, алар белән еш аралаша, хәтта ижади бәхәскә дә керә. Шуның нәтижәсендә бу әдипләр бер-берсенең ижатын яңа поэтик бизәкләр һәм алымнар белән баетып торалар.

Өченчедән, татар шагыйрьләренең 1960 еллар буыны Ренат Харис, Равил Фәйзуллин, Марсель Галиев, Роберт Миңнуллиннарга Мостай Кәрим өлкән әдип кенә түгел, ә ижади остаз, төрки халыкларның меңьеллык акыл чыганагы да булды, аларны үз ижат тәжрибәсе белән баетты. Шул рәвешле, татар әдәбиятына “Мостай мәктәбе" традицияләре дә үтеп керде, дип исәпләргә тулы нигез бар.

Төп төшенчәләр: шигърият, ижат, индивидуаль стиль, әдәби тәнкыйть, традиция, ижат ысулы, поэтик образ, символ.

һәр халыкның мәдәни яңарышында һәм сүз сәнгате күтәрелешендә зур роль уйнаган шәхесләре була. Алар милли әдәбиятның киләчәк үсеш юлын билгеләп кенә калмыйлар, ә элгәрге традицияләрне яңа сыйфатлар белән баетып, аны дөнья киңлекләренә алып чыгалар, башка кардәш халыклар әдәбияты үзгәрешенә дә йогынты ясыйлар. Башкортстан Республикасының халык шагыйре, язучы hәм драматург Мостай Кәрим (1919-2005) шундыйлардан санала. "Үз халкының ихлас сөюен, ныклы ихтирамын яулаган ижат кына башка милләтләр алдында шундый ук жаваплы сынауны үтә ала, - дип яза "Мостай Кәрим дәвере" дип аталган кереш мәкаләсендә Башкортстанның халык шагыйре Равил Бикбаев. - Чынлап та, Европа белән Азияне тоташтырган Урал туфрагына тамырланган Мостай Кәрим таланты, шушы жирлекнең тарихи хәтерен, тарихи горурлыгын да, хәзерге яшәү дәртен һәм киләчәк хакындагы хыялын да үзендә туплап үсте. Шул ук вакытта <..> Мостай Кәримнең ижат дөньясында башкорт сүз сәнгате тудырган традицияләр Көнчыгыш һәм Көнбатыш әдәбиятындагы, гомумән, дөнья мәдәниятендәге, тоташ кешелек хәзинәсендәге иң матур сыйфатлар белән үрелде" [Бикбаев, 10 б.]. Билгеле, әлеге табигый үрелешкә ирешү өчен, шагыйрьдән дөнья әдәбияты hәм мәдәнияте жәүһәрләре белән яхшы таныш булу, аларның әдәби-эстетик казанышларын ижади файдалану осталыгы таләп ителә.

Әлеге дәвамлы процесс, иң беренче чиратта, татар әдәбиятының меңьеллык традицияләрен өйрәну һәм ижади үзләштерүдән башланып, замандаш татар әдипләре белән ихлас аралашулар, бәхәсләр, фикер алышулар төсендә шагыйрьнең гомере буена дәвам итә. "Әле үсмер вакытымда, - дип хәтерли Мостай Кәрим, - татар шигыре белән яңа мавыга башлаган чагымда, ул поэзия минем күз алдыма ташлы юлдан жилдереп баручы тройка сыйфатында килеп баса иде. <..>. Тройка килә, туп-туры баскан тояк тавышлары шундый шигьри юлга әйләнә: “Татар Тукай... татар Такташ... татар Туфан..." [Кәрим, 2015: 147 б.].

Әлбәттә, М. Кәримнең татар халкы мәдәнияте һәм сүз сәнгате белән танышлыгының чишмә башы, “татар поэзиясенең күпгасырлык шәркый һәм милли традицияләрен ижади үзләштереп, аны Гаребнең эстетик казанышлары белән баеткан" [Гилазов, 2008: 45 с.] халык шагыйре Габдулла Тукай (1886-1913) ижатына барып тоташа. Ул бу даһиның юбилейларына багышланган тантаналы чараларның күбесендә катнаша, вакытлы матбугатта аның тормыш сукмаклары hәм шигъри дөньясы хакында күпсанлы мәкаләләр белән чыгыш ясый. Әдипнең татар шагыйренең 100 еллыгына багышланган “Тукай”, “Татар халкының бәхете булып..." (1986), 110 еллыгы уңаеннан язылган “Тукайга 110 яшь” (1996) мәкаләләре, юбилей тантаналарында сөйләгән чыгышлары Русия hәм Татарстан матбугатында да басылып чыга [Кәрим, 2015: 57-62 б.] ,[Кәрим, 2016: 251-253 б.], [Кәрим, 2016: 367-370 б.]. Аларда М. Кәрим башкорт халкының Тукай алдында “муеннан бурычлы” булуын билгели, аны, башкорт халкына мөгаллимлек итеп, мәгърифәт таратучыларның берсе һәм бик күренеклесе, башкорт әдәбиятына "остазлык итүчеләрнең иң атаклысы һәм иң якыны” дип атый. "Шуңа без, 
заманыбыздан артта калмас өчен, Тукайның чабуына килеп ябышабыз, көе киткән дөньябызның агышына төшенергә тырышып, аның акыл һәм күңел жимешләренә кайта-кайта мөрәжәгать итәбез. Юаныч түгел, таяныч эзлибез!" [Кәрим, 2016: 368 б.].

Мостай Кәрим шигъри дөньясының эчке хасиятендә, чынбарлыкны сурәтләү үзенчәлегендә Тукай традицияләре чагыла. Әдәбият галиме Суфиян Сафуанов (1931-2009) карашынча, “М. Кәрим ижатындагы киң карашлы, халыклар һәм илләр язмышы турында бертуктаусыз кайгыртып яшәгән тынгысыз шагыйрь-гражданин образы да үзенең күп кенә тамырлары белән Г. Тукай поэзиясенә барып тоташа. Аның "Уйлар" шигырендә: Tормыли бәйрәм түгел, тып-тын яшәп, / Шып-шымм гына дөнья куймамын, - дип чыгыш ясаган лирик герое татар халык шагыйре әсәрләрендәге "Сүзсез калмам газраилне күргәндә дә" дип жырлаган горур һәм актив лирик геройны хәтерләтеп куя. М. Кәримнең "Россиян мин" шигыре үзенең идея юнәлеше белән, урыс һәм башкортның “бер жепкә бергә теркәлеп яшәвен ачык күрсәтеп бирүе белән Г. Тукайның халыклар бердәмлеген раслаган патриотик әсәрләренә барып тоташмыймыни?" [Сафуанов, 40-41 б.]. Галим фикеренчә, аерым очракларда Тукайның халык ижаты нигезендә язылган әсәрләрендәге детальләр башкорт шагыйрьләренең шигырьләре hәм поэмаларының образлылык тукымасына катнаштырып жибәрелеп, әсәрнең эмоциональлеген, хис-тойгылар куәсен көчәйтә төшәләр. Менә М. Кәримнең "Таң жиле" балладасы. Әсәр шагыйрьнең тормыш, дөнья барышы турында уйланулары белән тулы. Әнә шул уйланулар, образлы ассоциацияләр рәтендә, һич көтмәгәндә, Г. Тукайның “Су анасы” әсәренең бер образлы детале килеп керә:

\begin{tabular}{|l|l|}
\hline Әлла бәхетсез су & Тилереп тик бер \\
кызыл, & ялгызы \\
Чәчен туздырып & Йөгереп күлне \\
шулай, & буйльй? \\
Урланган тарагын & \\
юллый, & \\
\hline
\end{tabular}

Әдәбият белән таныш кеше биредәге “урланган тарак” детале ярдәмендә М. Кәрим әсәрендәге образны Тукайның һәркемгә билгеле су анасы образына илтеп тоташтыра. Нәтижәдә шушы жыйнак кына образның мәгънә сыйдырышы зураеп китә, тулы һәм калку булып күз алдына баса [Сафуанов, 44-45 б.]. Тукайны өйрәнүче галимнәр “мәдәни багланышлар урнаштыруда һәм дөнья әдәби хәзинәсен баетуда шагыйрь ижатының зур өлеш кертүен билгелиләр" [Гилазов, 2016: с. 234].

M. Кәримнең композитор Заһир Исмәгыйлевкә (1916-2003) багышланган “Моңнар адашмый” (1997) мәкаләсенә эпиграф итеп Г.Тукайдан алынган шигъри юллар аның фәлсәфи фикер тирәнлеген ачуга хезмәт итә: "Күкрәгемда минем шигырь утым саумыз? - I Күтәрам мин карт булсам да авыр тауны" [Кәрим, 2016: 376-377 б.]. Шулай итеп, Тукайдагы образлылык М. Кәрим өчен әдәби осталык мәктәбе булып хезмәт итә, яисә ассоциация ярдәмендә яңа образлар ижат итүдә катнашып китә, әсәрләрендәге музыкальлекне арттыра.

Татар әдәбияты классигына чиксез ихтирамын hәм хөрмәтен Мостай Кәрим шигырьләре аша да чагылдыра. 1938 һәм 1997 елларда ул “Тукайга" дип исемләнгән ике шигырен яза һәм алар аша шагыйрь таланты алдында баш ия [Кәрим, 2009: 33 б.], [Кәрим, 2011: 204 б.]. Аларның беренчесендә Тукай образына, революцион поэзия эстетикасы яссылыгыннан, сыйнфый күзлектән чыгып бәя бирелсә (Искелекнең тынчу һавасында / Tыны бетеп Үлде яшь егет), икенчесендә исә шагыйрь поэзиясенә гомер буе сокланып яшәгән ижат кешесенең хисләре гомумкешелек аспектта ачыла (Алтмыш өч ел сиңа табынам, / Алтмыш өч ел сине сагынам). “Тукай” романы өчен беренче булып Г.Тукай исемендәге Татарстан Республикасы дәүләт бүләгенә лаек булган язучы, шагыйрь, әдәбият галиме Әхмәт Фәйзинең (1903-1958) вафаты уңаеннан язылган "Кичер әжәл" шигыре Мостай Кәримнең халык шагыйренә һәм Ә.Фәйзигә чиксез ихтирам hәм олылау хисләре белән сугарылган [Кәрим, 2011: 236 б.].

XX гасырның 80 елларындагы “үзгәртеп кору" чорында рухи идеалларны югалту сәбәпле, татар жәмәгатьчелегенең бер өлешендә, совет чоры классикларының ижади мирасын иләк аша үткәреп, үзләренең карашларына туры килмәгән әсәрләрен тарих чүплегенә ату теләге туа. Моңа үзенең тискәре мөнәсәбәтен белдереп, М. Кәрим 1991 елда “Өч Тулпар” шигырен яза һәм Тукай, Такташ, Туфан кебек шагыйрьләрне татар рухының терәге дип атый [Кәрим, 2011: 148 б.]. "Сәфәр" (2001) шигырендә ул, Тукай туган Кушлавыч, Такташ дөньяга килгән Сыркыды, Туфанны 
биргән Иске Кармәт авыллары алдында баш иеп, аларны hәр шагыйрьнең күңеле ашкынган изге урыннар дип атый [Кәрим, 2011: 233 б.]. “Экспромтлар" (2004) шигырендә дә татар шагыйрьләренең таланты лирик герой күңелендәге соклану хисенең сәбәбе булып тора:

Кайбердүләр утызга да жсттми

Тукай, Бабич, Такташ булганнар.

Сиксән биштә мин тик Мостай Кәрим

Ни кылаем инде, туганнар? [Кәрим, 2011: 245 б.].

Мостай Кәрим гомере буе татар әдәбияты тарихындагы өч “Т” - Тукай, Такташ, Туфан талантлары алдында баш иде, алардан шигъри ут алып, осталык серләренә өйрәнде, үз ижатын бәяләгәндә, бу шагыйрьләрне бизмән итеп куйды. Башкорт әдибенә аларның тәүге икесе белән очрашу, кызганычка каршы, насыйп булмый; Хәсән Туфан исә, аның шигъри Остазы булып кына калмыйча, ә тугры дустына да әверелә.

М.Кәрим күренекле шагыйрь Хәсән Туфан (1900-1981) шәхесе һәм ижаты белән узган гасырның утызынчы еллар башында ук, Чишмә районы Келәш авыл мәктәбендә укып йөргәндә, татар әдәбияты дәресләрендә таныша. “Беренче күргәндә, мин аны килештереп житмәдем. Кырыс йөзе, бигрәк тә иңбашына төшеп торган тузгак чәче (Пушкинныкы кебек бөдрә булса, бер хәл әле. - М.К.) күңелгә ятмады. Күрше Боголюбовка авылындагы чиркәу кагучы Семенның башы әнә шундый. Әтиемнең знакумы ул. Сүз, әлбәттә, Хәсән Туфаның дәреслек битендә басылган сурәте турында бара" [Кәрим, 2016: 253-254 б.], - дип яза ул әдиптән беренче алган тәэссораты турында. Туфанның төс-кыяфәте матурлардан булмаса да, аның шигърияте яшь Мостафа күңелендә жуелмас эз калдыра. “Андагы фикерләр һәм образлар яфрак өстендә әллә кайдан күренеп яткан вак кызыл жиләк түгел иде, ә яфрак астына посып, сыгылып-сыгылып төшкән сулы эре жимеш иде. Моны табу һәм күрү өчен, миңа байтак ел кирәк булды. Берзаман шулчаклы мавыктым, аның эзеннән ияреп китәсем килде. “Күршемнең теләге" дигән бер шигыремне “нәкъ Туфанча" китереп чыгарырга тырыштым. Ләкин килеп чыкмады. Туфанча язу өчен Туфан, тик Туфан гына булырга кирәклекне тиз аңладым. Әйткәндәй, әлеге иярчен шигырь теге елларда Хәсән аганың күзенә чалынган бердәнбер шигырем булган. Азактан үзе әйтте: “Шуны укыгач, бу малайда шаукым булмагае",
- дип уйлаган идем. Озын уналты ел буе: “Онытыгыз. Ул юк инде”, - дип тылкыдылар. Аның барын-югын ачык кына белмәсәк тә, күнел онытмады, ялган әмергә буйсынмады" [Кәрим, 2016: 260 б.].

Шагыйрьләр беренче тапкыр 1956 елның июнендә очрашалар. М. Кәрим сөргеннән кайткан Х.Туфанны Казанның тимер юлы вокзалына каршыларга килгән бердәнбер башкорт язучысы була [Кәрим, 2016: 260-261 б.]. Алга таба мөнәсәбәтләр ихласи дуслыкка әверелеп, аларның очрашулары елга берничә мәртәбә кабатлана [Туфан, 2010: 172-194 б.]. Көндәлекләрдән күренгәнчә, 1963 елның 10-16 гыйнвар көннәрендә Туфан Уфада була. Башкортстан Язучылар берлегенең чираттагы съездында катнаша; Башкорт дәүләт университетында студентлар каршында чыгыш ясый; каләмдәш дуслары Кадыйр Даян, Баязит Бикбай, Сәйфи Кудаш, Гыйлемдар Рамазанов, Ибраһим Абдуллин, Рәми Гарипов, Муса Гали, Нажар Нәжми, Фәрит Исәнголов, Әхтәм Мансур, Рафаэль Сафин, күренекле сәхнә осталары Арыслан Мөбарәков, Фәридә Кудашева һ.б.ларда кунак була. Кая гына бармасын, өлкән әдипне М. Кәрим озатып йөри. Ул аны Уфа вокзалында каршылап, соңгы көнне дә шуннан ук Казанга озата [Туфан, 2010: 172-173 б.]. Шул ук елның 7-11 февраль көннәрендә инде Башкортстан делегациясе составында М. Кәрим Казанга, Татарстан Язучылар берлеге съездына килә һәм, кунакханәгә урнашып тормыйча, Хәсән Туфанның йортында яши.

Күрәсең, ике әдипнең дуслык мөнәсәбәтләре бик тыгыз булгандыр, чөнки Туфан көндәлекләре шактый киселеп, күп кенә шәхси әйберләр басмага кермәгән. Мәсәлән, 7 февраль көне түбәндәге бер жөмлә белән генә чикләнә: 7/II “... Язган хатны яктылм, Хәсән абый: андый нәжсесне Казанга китерәсем килмәде", - ди Мостай” [Туфан, 2010: 175 б.]. Нинди хат бу? Туфан өстеннән югары даирәләргә (бу очракта: Башкортстан язучыларына. - И.Ф.) язылган шикаятьдоносмы, әллә, киресенчә, Мостай Кәримнең шундыйларга жавабымы? Башкорт әдибен тиргәп-сүгеп, Казаннан жибәрелгән хат булуы да мөмкин.

Х. Туфанның 1960 елда М. Кәримгә жибәрелгән өч хаты бүгенгәчә сакланган. Татар әдибенең 2010 елда дөнья күргән биштомлыгында басылган бу хатлар М. Кәрим шәхесенә тирән ихтирам, ижатына мәхәббәт 
хисләре белән сугарылган. Шул ук вакытта Туфанның Y3 шигъриятенә карата тыйнак мөнәсәбәте дә күзгә бәрелеп тора. Мәсәлән, 1960 елның 1 сентябрендә язылганында Хәсән Туфан болай ди: “Мин үзем өчен түгел, синең өчен шат: мин, дйтик кайбер шигырьда генд шагыйрь. Ә син шигырьдә генә түгел, мәкаләдә дә, мөгамдләдә дә; Казанда да, Кавказда да, Маскәүда дә; мәжслестә дә - һәрнарсәда, һәркайда да тоташтан шагыйрь. Сагындыра да ала торган, үткән генә түгел, синдә, ижсат, ж⿻анлы киләчәккә омтылыши булып тоелган сыйфат бар: киләчәкнең чиген тоя алу, ачык тоя алу көчле. Аның һәр сәгатенндн, һәр төнекөненндн матур яңалык табып булачагына ылшанасың, билгеле. Синең шигырь, һәр яңฺа шигырь никадәр бәхет бирә: мин читатель бит. һәм шактый азгын - һаман яхшыны гына эзләгән укучье" [Туфан, 2010: 284 б.].

Туфанның башкорт әдибенә хәерхаклы мөнәсәбәте Уфадагы каләмдәш дусларына язган хатларында да ачык чагыла. Мәсәлән, 1978 елда Нажар Нәжмигә 60 яшь тулу унаеннан жибәрелгән котлау телеграммасы түбәндәге кереш сүз белән башлана: "Башкортстан hәм Татарстан әдәбиятында балкып яшәгән энеләрем һәм сеңелләрем бар. Алар - Бәшир (Гомәр Бәширов. - И.Ф.), Сибгат (Сибгат Хәким. - И.Ф.), Мостай hәм син, Нажар" [Туфан, 2010: 286 б.]. 1930 елларда күпләрнең хыянәтен кичергән шагыйрьнең дуслар сайлауга ифрат житди каравын билгеләргә кирәк. Ике арадагы ихласи һәм ихтирами мөнәсәбәт Туфанның яшьлек дусты, "Галия" мәдрәсәсе буенча сабакташы, Сәйфи Кудашка (1894-1993) язган хатларында да ачык чагыла [Туфан, 2010: 239-283 б.].

1963 елның 22 апрелендә язган хатында Туфанның Мостай энесенә зур акыл иясе, дипломатия осталыгына ия булган шәхес итеп каравы ачык күренә. Анда сүз Башкортстан китап нәшриятында татар телендә жыентыклар чыгара башлау турында бара. Хәсән ага Башкортстанның халык шагыйре С. Кудашка бу эшне Мостай Кәрим белән киңәшләшеп, берлектә башкарып чыгарга тәкъдим итә. "Бу мөһим мәсьәлә эшкә ашмаган изге ният кенә булып калмасын, кабул булмаган теләк кенә булып калмасын иде" [Туфан, 2010: 242 б.]. Чынлап та, нәшриятта татар телендә китап бастыру эше жайга салынып, 1960 еллар уртасында берничә жыентык дөнья күреп тә өлгерә. Әлбәттә, бу озакка бармый республикада татар телендә китаплар 1990 елларда гына системалы рәвештә нәшер ителә башлый. Әлеге факт Х. Туфанның зур тормыш тәжрибәсе һәм дә М.Кәрим абруена ышанычы хакында сөйли.

$\mathrm{X}$. Туфан Мостай Кәримгә багышлап берничә шигырь яза. Казахстанда аларга багышланган “Татар әдәбияты hәм мәдәнияте" атналыгыннан кайтканда, поездда ижат ителгән "Чарчадык шактый кунакта...” [Туфан, 2008: 70 б.], башкорт шагыйренең 50 яшьлек юбилее уңаеннан дөнья күргән "Гамзат ич - безнең Рәсүл" (1969) [Туфан, 2007: 439-440 б.] шигырьләре шундыйлардан. 1967 елда Туфан Келәш авылына кунакка килә həм тагын аның күңелендә “Жил дә тынган, каеннар да уйчан" [Туфан, 2007: 80 б.] тезмәсе туа. Шагыйрь - М. Кәримгә багышланган лирик әсәрләрдән тыш, тәнкыйди һәм публицистик язмалар авторы да. Аның 1969 елда “Азат хатын” журналында М. Кәрим шәхесенең олпатлыгын, рухи мирасының байлыгын һәм кыйммәтен ачкан мәкаләсе дөнья күрә [Туфан, 2010: 45-46 б.].

Ижади дуслык, хезмәттәшлек берьяклы булып калмый, М. Кәрим үз чиратында X. Туфанга “Өч Тулпар" (1991) [Кәрим, 2011: 148 б.], “Сандугачка нигә буй-сын...” (1968) [Кәрим, 2011: 317 б. ] шигырьләрен багышлый. “Таңгы сәгать иде" (2001) әсәрендә Туфанның Казан янындагы “Аккош күле” бистәсендә урнашкан йортында ике шагыйрьнең очрашу хатирәсе яңартыла [Кәрим, 2011: 229 б.]. 2001 елда язылган "Казан” шигырендә М. Кәрим даһи Туфан аша шәһәргә үзенең мәхәббәтен белдерә [Кәрим, 2011: 228 б.]. “Тәңребез төшемә керде" (1994) әсәренә эпиграф итеп Туфанның “Ходайны күрдем төшемдә” дигән шигъри юлы алынган [Кәрим, 2011: 176 б.]. Башкорт әдибе шагыйрьнең 1960 елда Уфада чыккан "Күңел дәфтәреннән шигырьләр" жыентыгының кереш сүз авторы да булып тора [Туфан, 1960: 3-18 б.]. Хәсән Туфан ижатына багышланган күпсанлы мәкаләләре вакытлы матбугатта басылып чыга [Кәрим, 1960: 14 декабрь], [Кәрим, 1970: 106-112 б.] h.б. Күренә ки, М. Кәрим рухи мирасында Туфанга багышланган әсәрләр бер тематик тармакны барлыкка китерә.

М. Кәримнең татар әдипләре белән шәхси hәм ижади бәйләнешләре Бөек Ватан сугышы елларында аеруча ныгый. Бу уңайдан аның фронт газеталарындагы журналистлык hәм публицистик эшчәнлеген аерым билгеләргә кирәк. Шагыйрь "Гомер мизгелләре" дигән автобиографик әсәрендә язганча, 1943 елда аны Воронеж фронтында оештырылырга тиешле 
башкорт газетасына эшкә жибәрәләр. Ләкин басма, ни сәбәпледер, чыкмыйча кала, һәм Мостай Кәрим биредә рус телендә нәшер ителгән “За честь Родины” вакытлы матбугатында эшли башлый. Шул ук фронтта татарча "Ватан намусы өчен" газетасы да чыгып килгән була. М. Кәрим тиз арада шушы редакциядәге татар әдипләре Әхмәт Ерикәй (1902-1967) hәм Гали Хужи (1912-1966), драматург Риза Ишморат (1903-1995) белән белән танышып ала. Алар белән бер йортта яшәп, ярышып ижат итә. Үзе әйткәнчә, әлеге дуслык жепләре фронтовик әдипләрне гомерләренең соңгы көннәренә кадәр озатып бара [Кәрим, 2015: 498-499 б.].

1943 елның жәендә М. Кәримне 3 нче Украина фронтындагы “Совет сугышчысы” дигән татар басмасына эшкә күчерәләр. Аның мөхәррире вазифасын татар язучысы, тәржемәче Мәхмүд Мәсгут башкара. Әдип ижаты белән башкорт шагыйренең сугышка кадәр үк танышуы мәгълүм. Шәхси очрашу вакытында уңай тәэсир калдырган М. Мәсгут житәкчелегендә шагыйрь ике елга якын, сугыш ахырына кадәр языша. М. Кәримнең талантын баштан ук тоемлаган Мәсгут, шагыйрьгә ижат итәр өчен мөмкинлекләр тудыра. Шагыйрь "Гомер мизгелләре" китабында "Чит утлар" шигъри циклының, "Үлмәсбай” поэмасының өченче бүлегенең, "Башкорт халкына жавап хаты” шигыренең шул елларда язылуын билгели [Кәрим, 2002: 168-174 б.].

M. Мәсгут шагыйрь күңеленә тирән акыллы, гадел һәм таләпчән житәкче буларак мәңгелеккә кереп кала. Татар язучысы, Генрих Гейне әсәрләрен татарчага тәржемә итү максаты белән, алман телен махсус өйрәнә, сугыштан соң Гетенең “Фауст”ын татарчалаштырырга тели. Өстәвенә, шагыйрь-патриот Муса Жәлилнең якын дусты, ул гына да түгел, хәтта бажасы да була ул [Кәрим, 2015: 503 б.]. Бөек Ватан сугышының ахырында, М. Кәрим белән икәүләп, алар хәбәрсез югалган шагыйрьне эзлиләр, ләкин нәтижәсе булмый. Башкорт шагыйре эзләнүләр барышын "Үлемсезлекнең башлануы” (1966) мәкаләсендә жентекләп тасвирлый [Кәрим, 1999: 234- 238 б.]. Язмадан күренгәнчә, М. Кәрим 1940 елның көзендә Мәскәүнең Герцен урамында геройшагыйрь М. Жәлил (1906-1944) белән очраклы рәвештә очраша. Аңа хәтта якыннан аралашу форсаты да тими, чөнки Жәлил бу вакытта башкорт язучысы Әмир Чаныш белән сөйләшеп торган була [Кәрим, 2015: 74 б.]. Сугыштан соң ул татар шагыйренә багышланган берничә мәкалә язып бастыра [Кәрим, 1954: 94 б.], [Кәрим, 1966: 27 февраль], [Кәрим, 2015: 73-77 б.], Муса Жәлилнең 1976 елда Мәскәүдә рус телендә дөнья күргән “Сайланма әсәрләр”енә кереш сүз авторы була [Кәрим, 2015: 547 б.].

М. Кәрим күренекле татар галиме, фольклористы, драматургы һәм шагыйре Нәкый Исәнбәтнең (1899-1992) фәнни һәм әдәби ижатына зур хөрмәт белән карый. Алар берничә мәртәбә күрешәләр, даими хат алышалар, телефоннан сөйләшеп торалар. “Шундый очрашуларның берсе 1960 елның маенда Татарстандагы Кокушкино авылында уза. Моны Мостай Кәрим үзенең "Гомер мизгелләре" китабында тасвирлый [Кәрим, 2015: 521 б.]. Шагыйрь татар галименең 60 яшенә багышлап "Уракчыга алтмыш тулганда" (1960) шигырен яза hәм Н. Исәнбәтнең “Уракчы кыз” шигыреннән “Ай урагың сальп иңбашыңа..." дигән юлларны эпиграф итеп ала [Кәрим, 2015: 251 б.]. Соңыннан бу шигырь рус теленә дә тәржемә ителә" [Фазлетдинов, Хәлиуллина, 701 б.].

М. Кәрим татар әдәбияты вәкилләре белән шәхси һәм ижади дуслыгын үз мәкаләләрендә, интервьюларында даими ассызыклап бара: “Күңелемне монда әйдәгән дусларымнан Гариф Ахуновны, Туфан Миңнуллинны, Илдар Юзеевны, әлбәттә, Ренат Харисны әйтер идем. Янә Ринат Мөхәммәдиев, Равил Фәйзуллин, якташларыбыз Әхсән Баян, Роберт Миңнуллин, Гаташ... Шөкер, дуслар күп Казанда" [Кәрим, 2016: 321 б.]. Татарстанның халык язучысы, Г.Тукай исемендәге дәүләт премиясе лауреаты Г. Ахунов (1925-2000) белән дуслыгы 1960 еллар уртасыннан башлана. Татар язучысы башкорт шагыйренең өендә еш кунак була, аның юбилей кичәләрен алып бара. Мостай ага да Г.Ахуновның рәсми юбилей тантаналарында катнаша. Шуларның берсендә сөйләгән “Гомерең озын, картлыгың кыска булсын" дип аталган чыгышы башкорт әдәбияты классигының “Әсәрләр” тугыз томлыгында да басылып чыга [Кәрим, 2015: 354-356 б.]. Татар халык язучының ижаты гына түгел, ә исеме дә шагыйрьнең лирикасын поэтик бизәкләргә баета, фәлсәфи мәгънәсен тирәнәйтә. Аерым алганда, "Казан" шигырендә М. Кәрим аның исемен шәһәр символы буларак куллана [Кәрим, 2011: 228 б.].

М. Кәрим, ижат юлының башыннан ук диярлек татар драматургиясенең үсеш тенденцияләрен, казанышларын һәм житешсезлек- 
ләрен даими күзәтеп барып, аңа үз мөнәсәбәтен оператив һәм объектив рәвештә белдерә. Мәсәлән, 1974 елның июнь аенда Уфада башкорт һәм татар драматургларының, милли театрлар режиссерларының һəм театр белгечләренең киңәшмә-семинарында ясаган чыгышында ул башкорт театрының татар драматургиясеннән яралып, үсеп китүен билгели: "Без татар сәхнә сәнгатенең бүгенге хәленә карата һич кенә дә битараф кала алмыйбыз: уңышларга куанабыз, юньлесеннән өйрәнәбез, юньсезе өчен эчебез поша, хәвефләнәбез, ачынабыз" [Кәрим, 2017: 28 б.]. 1980 елның 24 октябрендә "Социалистик Татарстан” газетасындагы әңгәмәсендә, Туфан Миңнуллин (1935-2012) драматургиясенә сокланып, аны "Үз сүзен бөтен союз тамашачысына ирештерә алучы” [Кәрим, 2017: 123 б.] ижатчы дип атый.

Татарстанның халык язучысы, публицист hәм зур жәмәгать эшлеклесе Т. Миңнуллин үзе дә башкорт әдибе белән якын таныш була һәм аны милли мәдәниятнең корифее дип саный. Ике арада ижади мөнәсәбәтләр барлыкка килү сәбәпле, алар әдәби эшчәнлек һәм милли проблемалар буенча еш кына бәхәскә дә керәләр. Болар татар драматургының көндәлекләрендә һәм мәкаләләрендә теркәп калдырылганнар [Миңнуллин, 2002, 7 т.: 45 б.], [Миңнуллин, 2002, 7 т.: 268 б.], [Миңнуллин, 2002, 8 т.: 416-418 б.], [Миңнуллин, 2002, 10 т.: 239-243 б.]. Шунысы әһәмиятле: II Бөтендөнья Татар Конгрессында М. Кәрим татар язучысына үзенең китабын бүләк итә. Анда нечкә юмор белән тирән мәгънәле һәм гыйбрәтле "Жиңелгән укытучылан ж⿻иңче укучыма. Мостай Кәрим. 28.09.97” [Миңнуллин, 2002, 8 т.: 417 б.] дигән истәлек сүзләре язылган. Янә шунысы кызыклы: “Хушыгыз” драмасындагы бер күренешенең ижади чишелешен T. Миңнуллин М. Кәримнең "Кыз урлау" комедиясен караганнан соң төшендә күрә [Миңнуллин, 2002, 8 т.: 104 б.]. Аерым мәсьәләләрдә аларны фикер уртаклыгы берләштермәсә дә, тугандаш әдәбиятларның ике классигы бер-берсенең ижатына ихтирам белән карый.

М. Кәримне хәзерге татар әдипләре Ренат Харис, Роберт Миңнуллин, Марсель Галиев һ.б. белән дә тыгыз ижади һәм шәхси дуслык жепләре бәйли. Мәсәлән, 1997 елда ул, Р. Харисның “Хисемнең исеме" дип аталган шигъри жыентыгы Татарстан Республикасының Тукай бүләгенә дәгъва итүе уңаеннан, аңа рецензия яза. “Акыл да сөя, сүз дә уйната” дип исемләнгән әлеге язмасында ул каләмдәшен гареб-рус-татар әдәби бәйләнешләре контекстында карап, аны Федор Тютчев (1803-1873), Дәрдемәнд (1859-1921), Хәсән Туфан (1900-1981), Гарсия Лорка (1898-1938) белән “әдәби табындаш” дип атый. Шагыйрь әдәби дөньясының эчке хасияте, эчке моңы белән Дәрдемәнд лирикасына якынлыгын ассызыклый [Кәрим, 2016: 382 б.]. М. Кәрим Р. Хариска багышлап, "Иртәнге теләкләр" (2004) шигырен ижат итә [Кәрим, 2011: 244 б.].

“Марсель Галиев кәпәче" (1996) дип аталган язмасында башкорт шагыйре, гәрчә яшь аермасы 27 ел булса да, ижади карашлар якын булганлыктан, үзара мөнәсәбәтләрнең гади һәм кешелекле булуын әйтә [Кәрим, 2016: 375-376 б.]. Якташы Р. Миңнуллинның исеме, аңа бәйле гомер сәхифәләре аның бер төркем шигырьләрендә теркәлгән. 2002 елда язылган “Дусларга Яңа ел сәламнәре” шәлкемендә М. Кәрим шагыйрьгә һәм Р. Фәйзуллинга ихтирами мөнәсәбәтен нечкә юмор белән хисси-эмоциональ яссылыкта белдерә [Кәрим, 2011: 235 б.]. “Сәфәр” (2001) лирик әсәренә эпиграф итеп Р. Миңнуллинның “Шагыйрьләрнең туган жирләре” шигырендәге: Минем дуслар чит илләрга бара, / Чакыралар алар мине дә. / Хыялллары әйди дусларымны / Байрон яки Тагор иленд, -дигән юлларны ала һәм шунда ук жиңелчә шаяру рухы белән өретелгән "Онытммагыз, татар шагыйрыләре, / Туган жсирләр сезне сагына...” дигән икеюллыкны өстәп куя [Кәрим, 2011: 233 б.].

Татарстанның халык шагыйре Р. Миңнуллин исә "Малайлык. Осталык. Остазлык..." (1999) мәкаләсендә М. Кәримне: "Һичшиксез, дөнья әдәбиятының хәзерге заман классиклары белән янәшә торучы, алар белән рәхәтләнеп ярыша алучы әдип" [Миңнуллин, 2007, 5 т.: 182-184 б.], - дип атый. 2004 елның 14 октябрендә ижат ителгән "Иксез-чиксез Мостай бит ул!" язмасында башкорт әдибенең Татарстанның Түбән Кама шәһәрендәге “Жидегән чишмә" ижат берләшмәсе чакыруы буенча әдәбият сөючеләр белән очрашуга килүен ихласи бер жылылык белән тасвирлый [Миңнуллин, 2007, 6 т.: 272-278 б.]. Уфада нәшер ителгән “Атна" газетасындагы әңгәмәсендә ул: “Мостай абзый - минем өчен бик кадерле кеше, остазым, кечкенәдән укып үскән шагыйрем. Фикердәш, яшь аралары зур булса да, соңгы 10-15 ел уртак тел табып яшәдек. Киңәшләшеп, фикерләшеп. Хатлар 
алыштык, телефоннан сөйләшә идек. Күбрәк үзе шалтырата иде. <..>. Остаз буларак, мин аннан бик күп әйбергә өйрәндем" [Миңнуллин, 2007, 7 т.: 458 б.], - дип билгели.

М. Кәрим татар каләмдәшләре белән генә түгел, ә сәхнә әһелләре белән дә тыгыз дустанә мөнәсәбәтләрдә тора. 1994 елда аның 75 яшьлек юбилей тантаналары уңаеннан Уфага Казаннан данлыклы жырчы Хәйдәр Бегичев (1949-1998) килә. Шушы очрашудан соң М. Кәрим татар жырчысының ижатына да, шәхесенә дә гашыйк була, аның казанышларын аерым бер игътибар белән күзәтеп бара башлый. Бу мөнәсәбәттә кайгыртучанлык, кешелеклелек төсмере дә катнашкан. Мәсәлән, жырчының 1995 елда юл фажигасенә эләгү хәбәрен ишеткәч ул, Мәскәүдә, язучы Рауль Мир-Хәйдәров йортында, татар әдәбияты классигы Әмирхан Еникидән Y3 борчылуларын, теләктәшлеген белдергән шигырен һәм хатын жырчыга тапшыруны үтенә [Кәрим, 2016: 374 б.]. Эпиграфында "Хәйдәр Бегичевка" дип күрсәтелгән ул шигырь соңыннан шагыйрьнең "Әсәрләр" китабында басылып та чыкты [Кәрим, 2011: 198 б.].

"Үзе бер дәвер" (2005) дип аталган мәкаләсендә М. Кәрим татар эстрадасы легендасы, Татарстан Республикасының Г.Тукай исемендәге дәүләт премиясе лауреаты жырчы Илһам Шакиров (1835-2019) моңына сокланып, аны "могжсиза иясе, сихерче" дип атый: "Бөек Сара Садыйкованың минем сүзләргә язылган "Өченче көн тоташ кар ява"сын тыңлагач, ул елларда шундый күренеш кичердем: минем тәнемне озак еллар сызлаткан мина ярчыгын Илһам Шакиров, әйтерсең, Үз йөрәгеннән суырып алды. Ул жырлый, ә яралы йөрәгеннән ап-ак кар өстенә тамчы-тамчы кызыл кан тама...” [Кәрим, 2018: 36 б.].

Мостай Кәрим белән татар мәдәнияте вәкилләре арасындагы мөнәсәбәтләр турында сөйләгәндә, hәр татар зыялысын дулкынландырган туган (татар) тел, аның язмышы, Башкортстанда татар теле статусы мәсьәләсен читләтеп узу мөмкин түгел. Билгеле булганча, күп кенә әңгәмәләрендә шагыйрь республикада бер тел - башкорт теле генә дәүләт статусына ия булырга тиеш дигән фикерне яклап чыга. Рус теле исә, Русиянең дәүләт теле буларак, автоматик рәвештә әлеге дәрәжәгә ия була. Шул ук вакытта М. Кәрим 1992 елда башкорт зыялылары катнашлыгында үткән кызу фикер алышу барышында түбәндәге фикерне алга сөрә: "Бүгенге чынбарлыктан чыгып караганда, татар теленә дә аерым статус бирелергә тиештер. “Дәүләт теленнән кала татар теленең мәгърифәттә, мәдәнияттә, матбугатта, радиотелевидениедә, эш йөртүдә киң куллану даирәсен танырга" дигән кебегрәк. Анык кына төшенчәсен белгечләр ачыклар" [Кәрим, 2017: 186 б.]. Бу сүзләрдә Мостай Кәрим тирән фикерле, чын мәгънәсендә, интернационалист шәхес булып күзалдына килеп баса.

Башкорт халкының бөек шагыйре Мостай Кәрим Бөтенрусия, СССР халыкларының сүз сәнгатенә һәм мәдәниятенә зур йогынты ясый; аның ижатында күтәрелгән проблемалар, фикер-карашлар бер милләт белән генә чикләнмәгән, ә бәлки гомумкешелек мәгънәгә ияләр. Күзәтүләрдән чыгып, аның башкорт халкына тарихи һәм рухи-мәдәни яктан иң якын торган татар әдәбиятына һәм мәдәниятенә мөнәсәбәтендә, татар әдипләре белән рухи бәйләнешләрендә өч хасиятне күрсәтергә мөмкин. Беренчедән, Мостай Кәрим шигърияте татар халык авыз ижатыннан, татар әдәбияты корифейлары Г. Тукай, h. Такташ, М. Жәлил, Н. Исәнбәт салып калдырган традицияләрдән үсеп чыккан. Бу шагыйрьнең образлы фикерләвендә дә, ижатындагы дөнья картинасында да чагылыш таба. Икенчедән, еллар үтү белән, ул үзенең замандашлары - татар ижатчылары Х. Туфан, Г. Ахунов, И. Юзеев, Т. Миңнуллиннар белән тыгыз шәхси һәм ижади дуслык мөнәсәбәтләре урнаштыра, алар белән еш аралаша, хәтта бәхәскә дә керә. Бу әдипләр берберсенең ижатын яңа сәнгати образлар һәм алымнар белән баетып торалар. Өченчедән, яшьрәк буын татар әдипләре Р. Харис, Р. Фәйзуллин, М. Галиев, Р. Миңнуллиннарга Мостай Кәрим, өлкән каләмдәш кенә түгел, ә ижади остаз, төрки халыкларның меңьеллык акыл чыганагы да булып, аларны үз ижат тәжрибәсе белән баетты. Шул рәвешле, татар әдәбиятына "Мостай мәктәбе" традицияләре дә үтеп керде, дип исәпләргә тулы нигез бар. Башкортстанның халык шагыйре Р. Бикбаев сүзләре белән әйтсәк, бу аның “тормышчанлыгы һәм кешелеклелеге, уй-кичерешләренең фәлсәфи тирәнлеге, тапкыр образлылыгы, кабатланмас аһәңе-моңы белән" [Бикбаев, 11 б.] аңлатыла. Шулай итеп, М. Кәрим шәхесе həм ижаты, татар һәм башкорт сүз сәнгатьләре арасында үзенчәлекле рухи-мәдәни күперне хасил итеп, ике арадагы мөнәсәбәтләрне жайлауга, үзгә бер сәләт, табигый талант белән тудырылган байлык белән танышуга, тәжрибә уртаклашуга һәм алмашуга юл ача. 


\section{Әдәбият}

Кәрим М. Жыр хәбәрсез югалмады //Совет әдәбияты. 1954. №1. 94 б.

Кәрим M. Илебез горурлыгы // Совет

Татарстаны. 1966. 27 февраль.

Кәрим M. Картаймаучы шагыйрьләр шагыйре // Кызыл таң. 1960. 14 декабрь.

Миңнуллин Р. Әсәрләр: 7 томда: 5 т.: ижат портретлары, нотыклар, мәкаләләр. Казан: Татар. кит. нәшр., 2007. 431 б.

Миңнуллин $P$. Әсәрләр: 7 томда. 6 т.: публицистика, истәлекләр, нотыклар. Казан: Татар. кит. нәшр., 2007. - 527 б.

Миңнуллин Р. Әсәрләр: 7 томда: 7 т.: мәкаләләр, юлъязмалар, рецензияләр, әңгәмәләр. Казан: Татар. кит. нәшр., 2007. 527 б.

Миңнуллин T. Сайланма әсәрләр: 10 томда: 7 т.: Көндәлекләр (1980 - 1991 еллар). Казан: Татар. кит. нәшр., 2002. 448 б.

Миңнуллин T. Сайланма әсәрләр: 10 томда. 8 т.: Көндәлекләр (1980 - 1991 еллар). Казан: Татар. кит. нәшр., 2002. 479 б.

Миңнуллин T. Сайланма әсәрләр: 10 томда:10 т.: Әңгәмәләр, мәкаләләр. Казан: Татар. кит. нәшр., 2002. 400 б.

Туфан X. Сайланма әсәрләр: 5 томда: 2 т.: шигырьләр, поэмалар / Төзүчесе: Мәсгуд Гайнетдинов. Казан: Татар. кит. нәшр., 2007. 463 б.

Туфан X. Сайланма әсәрләр: 5 томда. 3 т.: шигырьләр, поэмалар / Төзүчесе: Мәсгуд Гайнетдинов. Казан: Татар. кит. нәшр., 2008. 415 б.

Туфан X. Әсәрләр: 5 томда. 4.: мәкаләләр, көндәлекләр, хатлар, төрле язмалар / Төзүчесе: Мәсгуд Гайнетдинов. Казан: Татар. кит. нәшр., 2010. 303 б. 376 б.

Сафуанов С. Рухи күперләр. Уфа: Китап, 2006.

Фазлетдинов И., Хәлиуллина А. Татарстаннан читтә ижат ителгән әдәбиятта татар мотивлары // Татар әдәбияты тарихы: сигез томда: 6. т.: 1960-1980 еллар / [төз. Р.Ф. Рахмани; фәнни мөх.: Д. Ф. Заһидуллина, Ә. М. Закиржанов]. Казан: Татар.кит.нәшр., 2018. Б.696-736.Туфан X. Сайланма әсәрләр: 5 томда. 3 т.: шигырьләр, поэмалар / Төзүчесе: Мәсгуд Гайнетдинов. Казан: Татар. кит. нәшр., 2008. 415 б.
Гилазов Т.Ш. Основные тенденции развития тукаеведения на рубеже XX-XXI веков // Ученые записки Казанского государственного университета. Том 150. Кн. 8. Гуманитарные науки. Казань: Изд-во Казанского государственного университета, 2008 C. 42-47.

Гилазов Т.Ш. Академическое собрание сочинений Габдуллы Тукая: история, структура и принципы составления // Филология и культура. Philology and Culture. 2016. №(44). C.230-237.

Карим М. Избранное: стихотворения, поэмы, сказки, трагедии. М.: Художественная литература, 1973. $152 \mathrm{c}$.

Карим М. Притча о трех братьях. М.: Современник, $1988.367 \mathrm{c}$.

Карим М. Стихи и поэма / пер. с башкир. яз. М.: Советская Россия, 1982. 256 с.

Карим М. Ушел, не помня зла // Вечерняя Казань. 1982. 12 октября.

Бикбаев P. Мостай Кәрим дәүере // Кәрим Мостай. Әсәрзәр. 1 т.: шиғырзар. Өфө: Китап, 2009. Б. 7-18.

Кәрим М. Ғүмер мизггелдәре. Өфө: Китап, 2002. 336 б.

Кәрим M. Йөрәгендә етмеш яз йөртөүсе //Ағизел. 1970. №12. 106-112 б.

Кәрим М. Көндәлектәр //Ағизеел. 2006. №10. Б. 5 -39 .

Кәрим М. Әсәрз̧әр: 1 т.: шиғырз̧ар. Өфө: Китап, 2009. 512 б.

Кәрим М. Әсәрзәр: 2 т.: шиғырзар, шиғри тәржемәләр. Өфө: Китап, 2011. 416 б.

Кәрим М. Әсәрзәр: 5 томда: 4 т.: ис̧тәлектәр, мәкәләләр, телмәрзәр, әңгәмәләр. Өфө: Башкортостан «Китап» нәшриәте, 1999. 592 б.

Кәрим М. Әсәрзəр: 6 т.: хәтирәләр, әзəби һүрәтләмәләр. Өфө: Китап, 2015. 560 б.

Кәрим М. Әсәрзәр: 7 т.: һайланма публицистик язмалар. Өфө: Китап, 2016. 568 б.

Кәрим М. Әсәрзәр: 8 т.: сығыштар, телмәрзәр, әңгәмәләр. Өфө: Китап, 2017. 472 б.

Кәрим М. Әсәрзәр: 9 т.: мәкәләләр, сығыштар, телмәрзәр, әңгәмәләр, монологтар. Өфө: Китап, 2018. 520 б.

Туфан X. Күңел дәфтәренән шигырзар / кереш hүз авт. М. Кәрим. Өфө: Башкортостан китап нәшриәте, 1960. 208 б. 


\title{
МУСТАЙ КАРИМ И ТАТАРСКАЯ ЛИТЕРАТУРА: ЛИТЕРАТУРНОЕ МАСТЕРСТВО И НАСТАВНИЧЕСТВО
}

\author{
Ильдус Камилович Фазлутдинов, \\ Башкирский государственный университет, \\ Россия, 450076, г. Уфа, ул. Заки Валиди., д. 32, \\ fazlutdinov75@mail.ru.
}

\begin{abstract}
В статье исследуются личные и творческие контакты Мустая Карима с татарскими писателями сквозь призму наработок современного литературоведения. Автор в своей работе руководствуется хронологическим и диахронным методами анализа. В статье доказано, что великий поэт башкирского народа оказал огромное влияние на культуру и искусство народов СССР, преодолев узконациональные рамки, проблематика его произведений стала носить общечеловеческий характер. В ходе анализа личных и творческих контактов М. Карима с татарскими писателями и деятелями культуры был выявлен ряд особенностей.

Во-первых, огромную роль в становлении его поэзии сыграли традиции татарского фольклора и творчество таких корифеев татарской литературы, как Габдулла Тукай, Хади Такташ, Муса Джалиль, Наки Исанбет. Это нашло воплощение в художественной картине мира его произведений, в эстетическом оформлении поэтической мысли. Так, при создании новых образов действительности М. Карим опирался на традиции, заложенные Г. Тукаем, это повлияло и на музыкальность его произведений. Во-вторых, крепкая дружба с татарскими писателями Хасаном Туфаном, Гарифом Ахуновым, Ильдаром Юзеевым, Туфаном Миннуллиным не мешала М. Кариму вступать с ними в творческую полемику: они обогащали творчество друг друга новыми поэтическими образами и приемами выразительности.

В третьих, для поколения поэтов - татарских шестидесятников: Рената Хариса, Равиля Файзуллина, Марселя Галиева, Роберта Миннуллина - он превратился в поэта-наставника. Это позволило литературоведам ввести понятие «Школа Мустая».
\end{abstract}

Ключевые слова: поэзия, творчество, индивидуальный стиль, литературная критика, традиция, творческий метод, поэтический образ, символ. 